\title{
Daidzein induces neuritogenesis in DRG neuronal cultures
}

\author{
Shih-Hung Yang ${ }^{1,2}$, Chih-Chen Liao ${ }^{1}$, Ying Chen ${ }^{3}$, Jhih-Pu Syu ${ }^{1}$, Chung-Jiuan Jeng ${ }^{4^{*+}}$ and Seu-Mei Wang ${ }^{2^{*+}}$
}

\begin{abstract}
Absract
Background: Daidzein, a phytoestrogen found in isoflavone, is known to exert neurotrophic and neuroprotective effects on the nervous system. Using primary rat dorsal root ganglion (DRG) neuronal cultures, we have examined the potential neurite outgrowth effect of daidzein.

Methods: Dissociated dorsal root ganglia (DRG) cultures were used to study the signaling mechanism of daidzeininduced neuritogenesis by immunocytochemistry and Western blotting.

Results: In response to daidzein treatment, DRG neurons showed a significant increase in total neurite length and in tip number per neuron. The neuritogenic effect of daidzein was significantly hampered by specific blockers for Src, protein kinase $C$ delta (PKC $\delta$ ) and mitogen-activated protein kinase/extracellular signal-regulated kinase kinases (MEK/ERK), but not by those for estrogen receptor (ER). Moreover, daidzein induced phosphorylation of Src, PKC $\delta$ and ERK. The activation of PKC $\delta$ by daidzein was attenuated in the presence of a Src kinase inhibitor, and that of ERK by daidzein was diminished in the presence of either a Src or PKC $\delta$ inhibitor.
\end{abstract}

Conclusion: Daidzein may stimulate neurite outgrowth of DRG neurons depending on Src kinase, PKC $\delta$ and ERK signaling pathway.

Keywords: Daidzein, DRG neuronal culture, Neurite outgrowth, Signaling mechanism

\section{Background}

Daidzein, found mainly in soy food products and herbs like red clover [1,2], is one of the most studied and most potent phytoestrogens. Phytoestrogens are estrogenic compounds of plant origin, and have structures and functions similar to the mammalian endogenous hormone estrogen [3]. Both estrogen and phytoestrogens can bind to intracellular estrogen receptors (ERs) to trigger downstream signal transduction pathways and achieve various biological functions [4]. Phytoestrogen acts mainly as an ER agonist. It may also function as an antagonist, by inhibition of aromatase activity in breast cancer cells, and blockage of estrogen uptake by uterine cells [5]. This mixed ER agonist/antagonist property probably explains the potential benefit of phytoestrogen in breast cancer prevention [6-8].

\footnotetext{
* Correspondence: cjjeng@ym.edu.tw; smwang@ntu.edu.tw

${ }^{\dagger}$ Equal contributors

${ }^{4}$ Institute of Anatomy and Cell Biology, School of Medicine, National YangMing University, No. 155, Section 2, Li-Non Street, Taipei 12212, Taiwan ${ }^{2}$ Department of Anatomy and Cell Biology, College of Medicine, National Taiwan University, No. 1, Section 1, Jen-Ai Road, Taipei 10051, Taiwan

Full list of author information is available at the end of the article
}

In response to ligand binding, ERs can signal through both genomic (classical) and non-genomic (non-classical) pathways $[9,10]$. In the genomic pathway, upon binding to estrogen, ERs dimerize and interact with the estrogen responsive element (ERE) in the regulatory regions of estrogen responsive genes, thereby regulating the transcription of E2sensitive genes, e.g. c-fos, TGF- $\alpha$, and angiotensinogen [9]. The non-genomic pathway involves the activation of other signal transduction pathways that lead to rapid and diverse physiological responses, including calcium and potassium influxes through cell membrane, and activation of second messenger systems such as cAMP/PKA, MAPK, PI3K/Akt, and $G$ protein $[10,11]$. The precise mechanisms of nongenomic effects of estrogen are not clear and have been suggested to be mediated by membrane-associated ER $\alpha$, ER $\beta$, or the orphan G-protein-coupled receptor 30 (GPR30) $[12,13]$. Activation of non-nuclear ER $\alpha$, for example, can stimulate endothelial cell proliferation via G protein, Src, and eNOS activation [14]. In cultured osteoblastic cells, daidzein has been suggested to activate a non-classical

\section{Biomed Central}

(c) 2012 Yang et al.; licensee BioMed Central Ltd. This is an Open Access article distributed under the terms of the Creative Commons Attribution License (http://creativecommons.org/licenses/by/2.0), which permits unrestricted use, distribution, and reproduction in any medium, provided the original work is properly cited. 

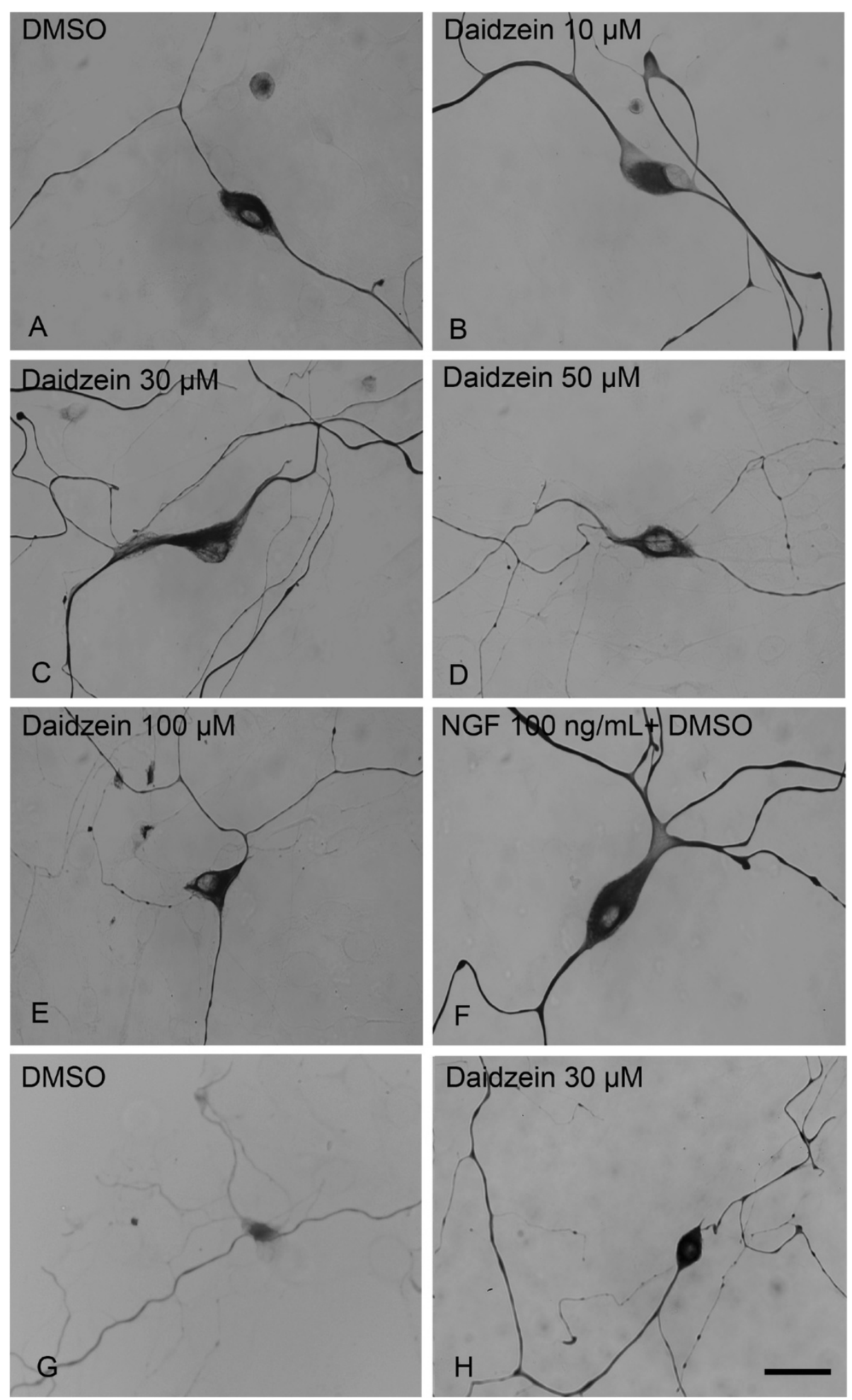

Figure 1 Induction of neurite outgrowth of cultured rat DRG neurons by daidzein and NGF. DRG neuronal cultures were treated for $24 \mathrm{~h}$ with (A) DMSO, (B-H) various concentration of daidzein, or (F) NGF (100 ng/ml), then fixed and immunostained for NF-L. A-F, large neurons. G-H, small neurons. Scale Bar $=30 \mu \mathrm{m}$. 


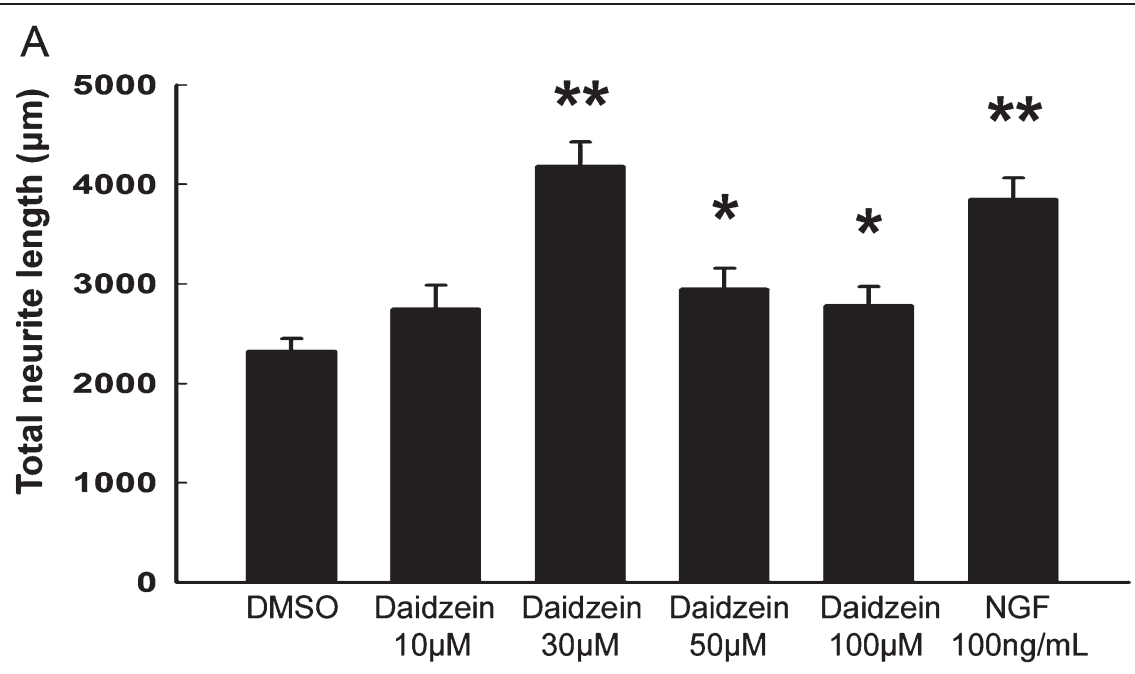

B

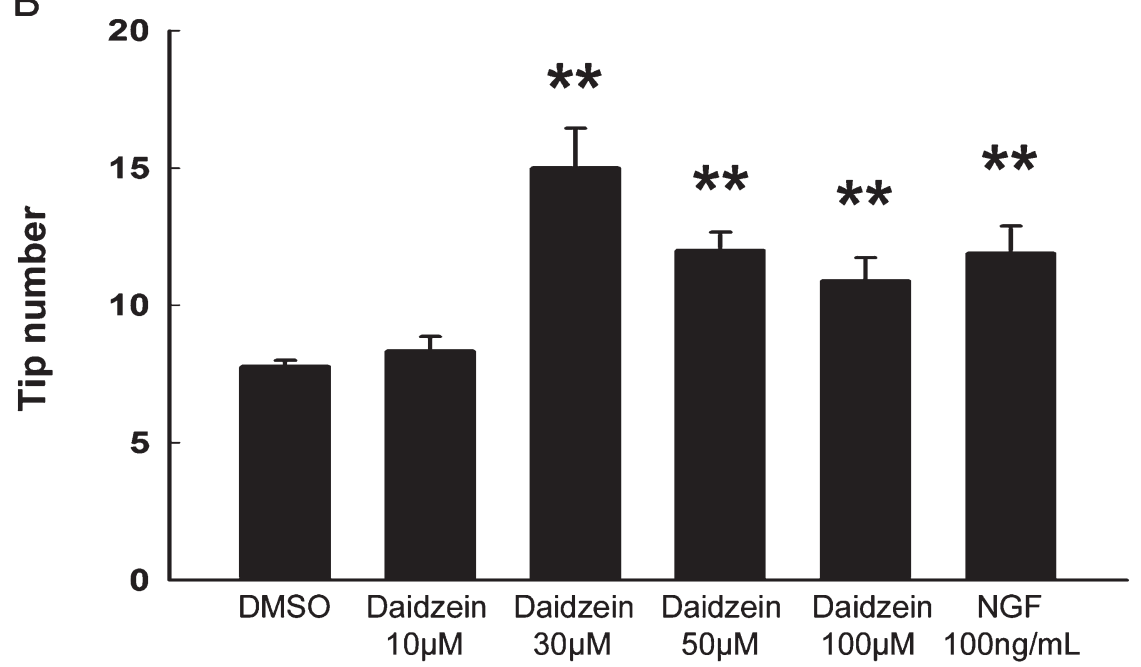

C

Small neuron
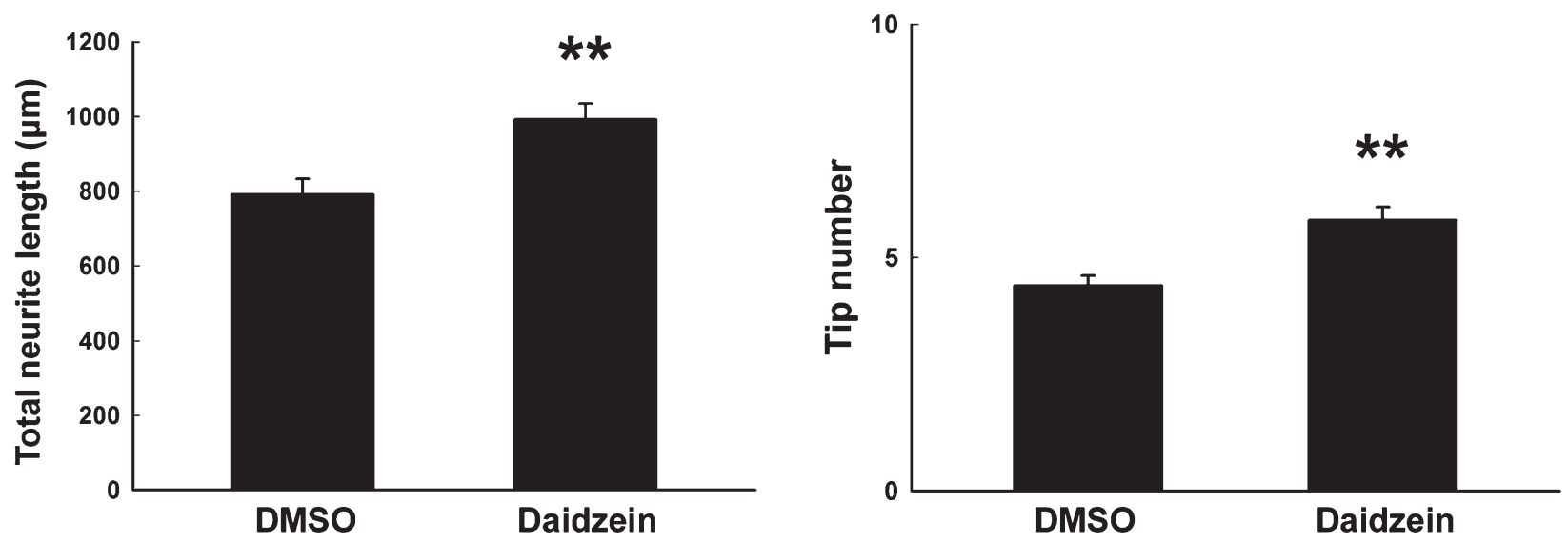

Figure 2 (See legend on next page.) 
(See figure on previous page.)

Figure 2 Quantitative analysis of total neurite length and tip number of neurite branches per neuron following various treatments with DMSO, daidzein, or NGF. Significant neurite lengthening and branching were observed in both large (A and B) and small DRG neurons (C) treated with $30 \mu \mathrm{M}$ daidzein or $100 \mathrm{nM}$ NGF. Three independent experiments were performed. Ten neurons were chosen from each group in one representative experiment for analysis. ${ }^{*}, \mathrm{p}<0.05$ vs DMSO controls. ${ }^{* *}, \mathrm{p} \leq 0.01$ vs DMSO controls.

membrane ER- $\beta$ pathway that involves phospholipase $C-\beta 2$ (PLC- $\beta 2) /$ PKC and PI3K/CSrc [15].

Emerging evidence, however, indicates that for some of the phytoestrogen effects, ER activation may not be required. For instance, genistein, a rich phytoestrogen in soybeans, was shown to exert growth inhibitory effects in ER-negative breast cancer cells [16-18]. Compared to $17-\beta$ estradiol, the most biologically active estrogen in mammals, daidzein has a significantly lower affinity for both ER- $\alpha$ and ER- $\beta$ [19]. Moreover, daidzein could induce anti anti-proliferative effects in both ER-positive and ER-negative pancreatic cells [20]. Together these observations raise the possibility that daidzein may also exert its pharmacological effect via an ER-independent signaling pathway.

Daidzein is known to exert significant neuronal protection and neuritogenic effects for a variety of cultured neuronal cells, e.g. hippocampal neurons, cortical neurons, dorsal root ganglion (DRG) neurons, and PC12 cells [21-24]. In hippocampal neuron, the neuritogenic mechanism involves ER $\beta$-PKC $\alpha$-GAP43 signaling. To further understand the diversity of the intracellular signaling mechanisms of daidzein, in the current study we focused on daidzeininduced neurite outgrowth in cultured DRG neurons. DRG culture is a well-characterized system for investigating the mechanism of neuritogenesis [25-27], and for screening neuroprotective drugs for peripheral neuropathies [28]. Studies using DRG cultures have shed light on the pathogenic mechanisms of peripheral nervous system diseases and the regeneration of spinal cord injury [29-31]. Here we showed that in cultured DRG neurons daidzein induced notable neuritogenesis via an ER-independent signaling pathway. In addition, we presented several lines of evidence suggesting that daidzein-induced neurite outgrowth in DRG neurons may be primarily mediated by the Src kinase, PKC $\delta$ and ERK signaling pathway.

\section{Methods}

\section{Drugs}

Daidzein was purchased from the Pharmaceutical Industry Technology and Development Center (New Taipei City, Taiwan). Nerve growth factor (NGF) was purchased from R\&D Systems (Minneapolis, MN, USA). Dimethyl sulfoxide (DMSO), antibodies for neurofilament light chain (NF-L) were purchased from Sigma Chemical Co. (St. Louis, MO, USA). L-15 Leibovitz medium was purchased from Gibco (Grand Island, NY, USA). ER antagonists ICI182780, tamoxifen and G-protein coupled receptor 30 (GPR-30) antagonist G15 were obtained from TOCRIS (TOCRIS Cookson Inc., Bristol, UK). Src kinase inhibitor PP2, MEK inhibitor U0126, PKC inhibitor staurosporin, and PKCS inhibitor rottlerin were purchased from Biomol Research Laboratory Inc. (Plymouth meeting, PA, USA).

\section{Animals}

Postnatal day 2 Wistar rat pups were purchased from the Facility for Animal Research of the National Taiwan University. All procedures were in accordance with the Guidelines for the Care and Use of Mammals in Neuroscience and Behavioral Research (National Research Council 2003) and approved by the Institutional Animal Care and Use Committee (IACUC) of National Taiwan University, College of Medicine.

\section{Cell culture}

DRG cultures were prepared as described previously [25]. Briefly, P2 rat pups were put on ice and then decapitated to harvest DRG. DRG were then dissected out under microscope and dissociated with $0.25 \%$ trypsin and $0.05 \%$ collagenase (Sigma) in HBSS solution, for $30 \mathrm{~min}$ at $37^{\circ} \mathrm{C}$. These ganglia were then dispersed by mechanically trituration with glass pipettes. The pellet from low-speed centrifugation was re-suspended in phenol-red free L-15 Leibovitz media, supplemented with $1.2 \mathrm{~g} / \mathrm{L}$ of $\mathrm{NaHCO}_{3}, 5 \%$ fetal bovine serum, $100 \mathrm{IU} / \mathrm{mL}$ of penicillin, and streptomycin (Gibco). Cells were plated on collagen-coated coverslips for immunocytochemistry, and on $35 \mathrm{~mm}$ uncoated culture dishes for protein quantification by Western blot. The medium was changed to serum free L-15 for day in vitro (DIV) 2 cultured DRG cells. Cultures were maintained at $37^{\circ} \mathrm{C}$ in an atmosphere of $95 \%$ air and $5 \% \mathrm{CO}_{2}$.

\section{Cell survival assay}

The MTT assay, a colorimetric assay for measuring the activity of mitochondrial enzymes, was used to examine whether cell viability was affected by treatmen [32]. In each well of 24-well culture plates, $2 \times 10^{4}$ cells were plated and were treated with $0.1 \%$ DMSO, different concentration of daidzein or different kinase inhibitors for $24 \mathrm{~h}$. After treatments, cells were washed with phosphate-buffered saline (PBS; $137 \mathrm{mM} \mathrm{NaCl}, 2.7 \mathrm{mM} \mathrm{KCl}, 1.5 \mathrm{mM} \mathrm{KH_{2 }} \mathrm{PO}_{4}$, $8 \mathrm{mM} \mathrm{Na}_{2} \mathrm{HPO}_{4}, \mathrm{pH} 7.4$ ), and incubated in $0.5 \mathrm{mg} / \mathrm{ml}$ of 3-[4, 5-dimethylthiazol-2-yl]-2, 5-diphenyltetrazolium bromide (MTT) solution for $4 \mathrm{~h}$ to allow the conversion of 

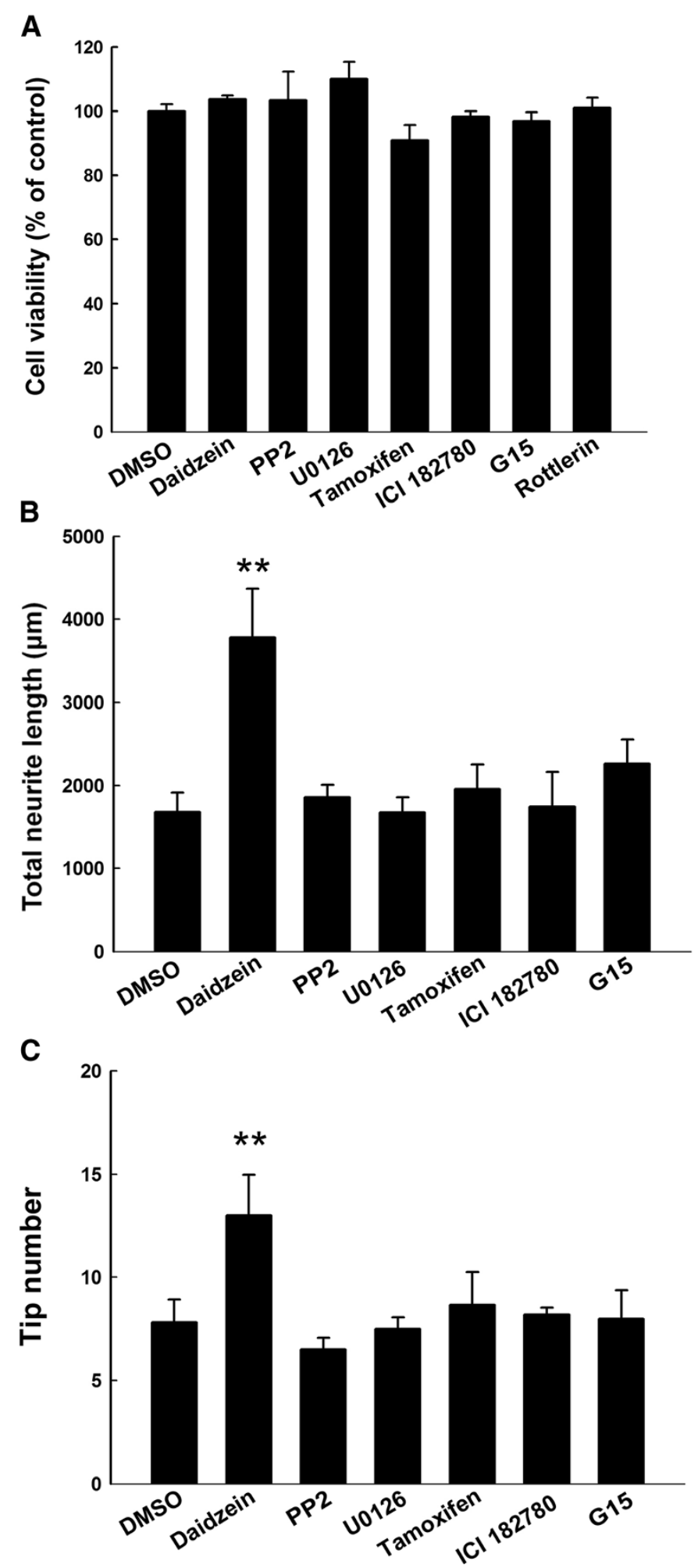

Figure 3 Effect of different inhibitors on cell viability and neuritogenesis. DRG neurons were treated with $0.1 \%$ DMSO, $30 \mu \mathrm{M}$ diadzein, 10

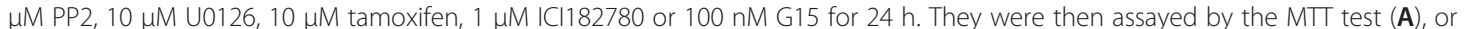
immunostained for NF-L and analyzed for total neurite length (B) and tip numbers (C). 


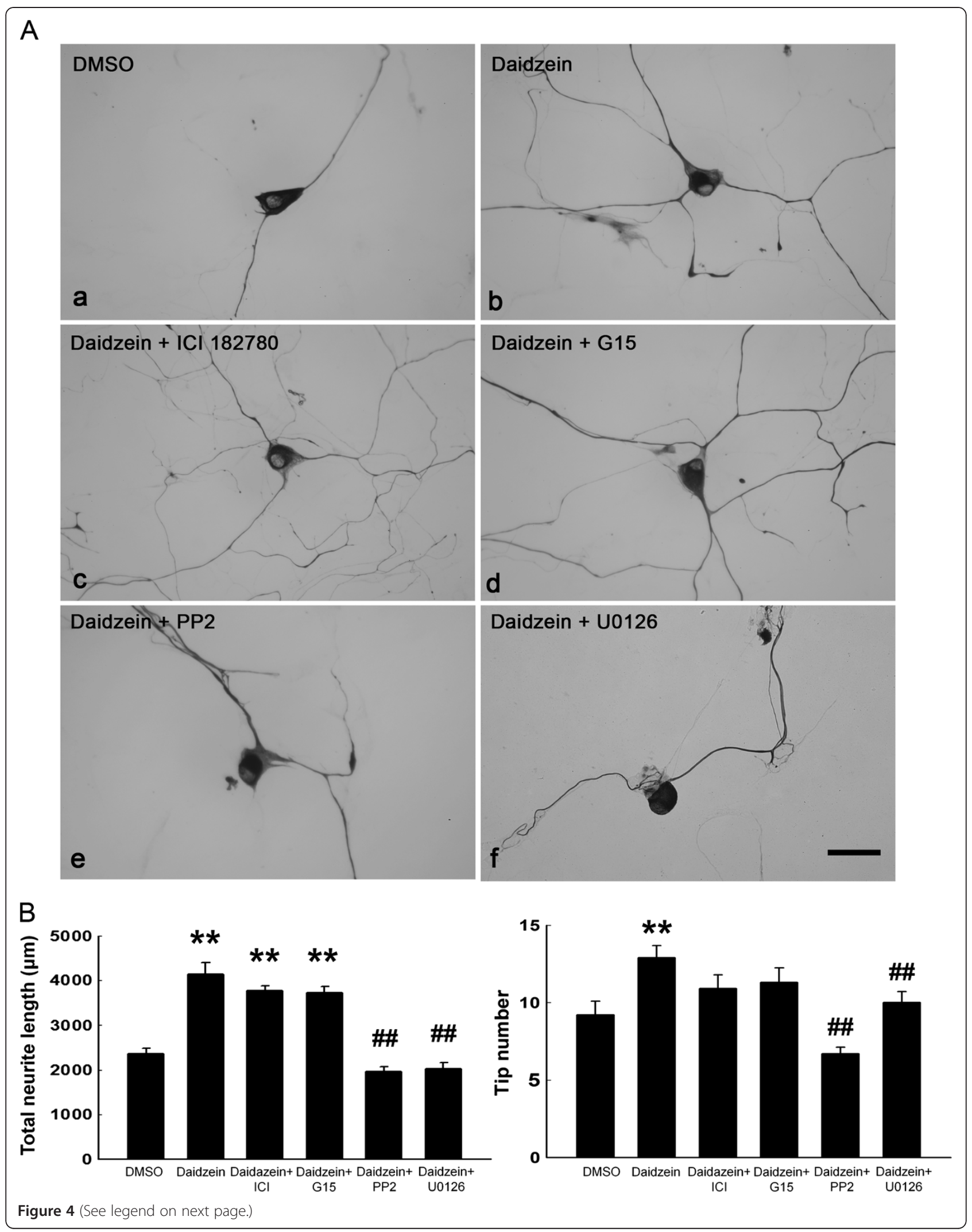


MTT into the purple formazan product by mitochondrial dehydrogenases. The reaction medium was then removed and the cells were lysed with DMSO for $5 \mathrm{~min}$. The absorbance was read at $590 \mathrm{~nm}$ with a spectrophotometer (Beckman Coulter Inc., Fullerton, CA).

\section{Drug treatment}

DIV 3 cultured DRG cells received either daidzein at a concentration of $10 \mu \mathrm{M}, 30 \mu \mathrm{M}, 50 \mu \mathrm{M}$, or $100 \mu \mathrm{M}$, vehicle solution DMSO (final concentration of $0.1 \%$ ), or NGF of $100 \mathrm{ng} / \mathrm{mL}$, in order to study the effect of daidzein on neurite outgrowth.

For inhibitor assay, one of following inhibitors was reacted $30 \mathrm{~min}$ before the addition of daidzein: estrogen receptor antagonists ICI182780 at $1 \mu \mathrm{M}$ and tamoxifen at $10 \mu \mathrm{M}$; GPR-30 inhibitor G15 at $100 \mathrm{nM}$; Src kinase inhibitor PP2 at $10 \mu \mathrm{M}$; PKC inhibitor staurosporin at $100 \mathrm{nM}$; PKC $\alpha / \beta$ inhibitor Gö6976 at $1 \mu \mathrm{M}$; PKCE inhibitor $€ \mathrm{~V} 1-2$ at $2 \mu \mathrm{M}$; PKC $\delta$ inhibitor rottlerin at $2 \mu \mathrm{M}$; MEK inhibitor U0126 at $10 \mu \mathrm{M}$.

\section{Immunocytochemistry}

After $24 \mathrm{~h}$ of DMSO or daidzein treatment, DRG neurons on cover glasses were fixed for $10 \mathrm{~min}$ with $10 \%$ formalin in PBS. After washed with PBS, cells were then permeabilized and blocked with $0.15 \%$ Triton X-100 and 5\% non-fat milk in PBS for $1 \mathrm{~h}$. DRG neurons were then incubated in mouse anti-NF-L antibody overnight at $4^{\circ} \mathrm{C}$. After PBS wash, cells were incubated in biotin-conjugated goat antimouse IgG (Vector, Burlingame, CA, USA) at 1:50 dilution for $1 \mathrm{~h}$ at room temperature, washed with PBS, then reacted with avidin-biotinylated enzyme complex (Vector) for one hour at room temperature. Following PBS wash, staining was done with peroxidase-chromogen reaction (SG substrate kit, Vector), which was stopped by Trisbuffered saline (TBS: $50 \mathrm{mM}$ Tris-Base, $150 \mathrm{mM} \mathrm{NaCl}$, $\mathrm{pH}$ 8.2). Coverslips were then dehydrated by ethanol and xylene, and mounted with Permount (Fisher Scientific, $\mathrm{NH}$, USA). Images were taken on a light microscope, equipped with a Nikon DIX digital camera (Nikon, Tokyo, Japan).

\section{Western blotting}

After various treatment, the cultured DRG neurons were homogenized in ice-cold lysis buffer solution
(10 mM EGTA, $2 \mathrm{mM} \mathrm{MgCl}_{2}, 0.15 \%$ Triton X-100, $60 \mathrm{mM}$ PIPES, $25 \mathrm{mM}$ HEPES, pH 6.9, containing $1 \mu \mathrm{M}$ phenylmethylsulfonyl fluoride, $1 \mu \mathrm{M} \mathrm{NaF}, 10 \mu \mathrm{g} / \mathrm{ml}$ of leupeptin and $1 \mu \mathrm{g} / \mathrm{ml}$ pepstatin) and sonicated. A 3fold volume of $4 \mathrm{X}$ reducing SDS sample buffer was added to each lysate and boiled at $95^{\circ} \mathrm{C}$ for $5 \mathrm{~min}$. Fifty microgram of protein from each sample (protein concentration determined by Bio-Rad protein Kit, Bio-Rad Lab, CA, USA) were separated by $10 \%$ polyacrylamideSDS gel electrophoresis, electrotransferred to nitrocellulose membrane (Schleicher and Schuell, Keene, NH, USA), blocked by TBS containing $5 \%$ non-fat milk and $0.1 \%$ Tween-20, and then incubated overnight at $4{ }^{\circ} \mathrm{C}$ with the following primary antibodies: rabbit antipTyr527-Src (Cell Signaling) at 1: 500 dilution; rabbit anti-pThr505 PKC (Epitomics, Burlingame, CA, USA) at 1:500 dilution and rabbit anti-PKC $\delta$ (Santa Cruz, Santa Cruz, CA, U.S.A.) at 1:500 dilution; mouse antipThr and anti-pTyr ERK (Sigma) at 1:1000 dilution and rabbit anti-ERK1/2 (Santa Cruz) at 1:500 dilution; mouse anti-cSrc (Millipore, Billerica, MA, USA) at 1:300 dilution. Following washes with TBS containing $0.1 \%$ Tween-20, alkaline phosphatase conjugated secondary antibodies at 1:7500 dilution (Promega, Madison, WI, USA) were added for an hour at room temperature, and the bound antibodies visualized using enzyme-substrate reaction (substrate: $3.3 \mathrm{mg} / \mathrm{ml}$ nitro blue tetrazolium and $1.65 \mathrm{mg} / \mathrm{ml}$ 5-bromo-4-chloro-3indolyl phosphate in $100 \mathrm{mM} \mathrm{NaCl}, 5 \mathrm{mM} \mathrm{MgCl}$, 100 mM Tris-base, $\mathrm{pH}$ 9.5).

\section{Quantification}

Immunostained neurons were photographed at $20 \times$ or $40 \times$ (for morphological demonstration) magnification, and the images transformed into 256 gray scale images. The fields were chosen to locate individual neuron with discernible neurites from nearby neurons. Generally, an average of 2-4 neurons could be seen in a micrograph taken at $20 \times$ magnification. The total neurite length was then measured from the somata using a PC-based image analyzer software Image Pro 3.0 Plus (Media Cybernetics, Silver Spring, MD, USA). The signal intensity of bands stained on immunoblot was quantified with Gel pro 3.1 (Media Cybernetics). Student's $t$-test was used for evaluating statistical differences between 

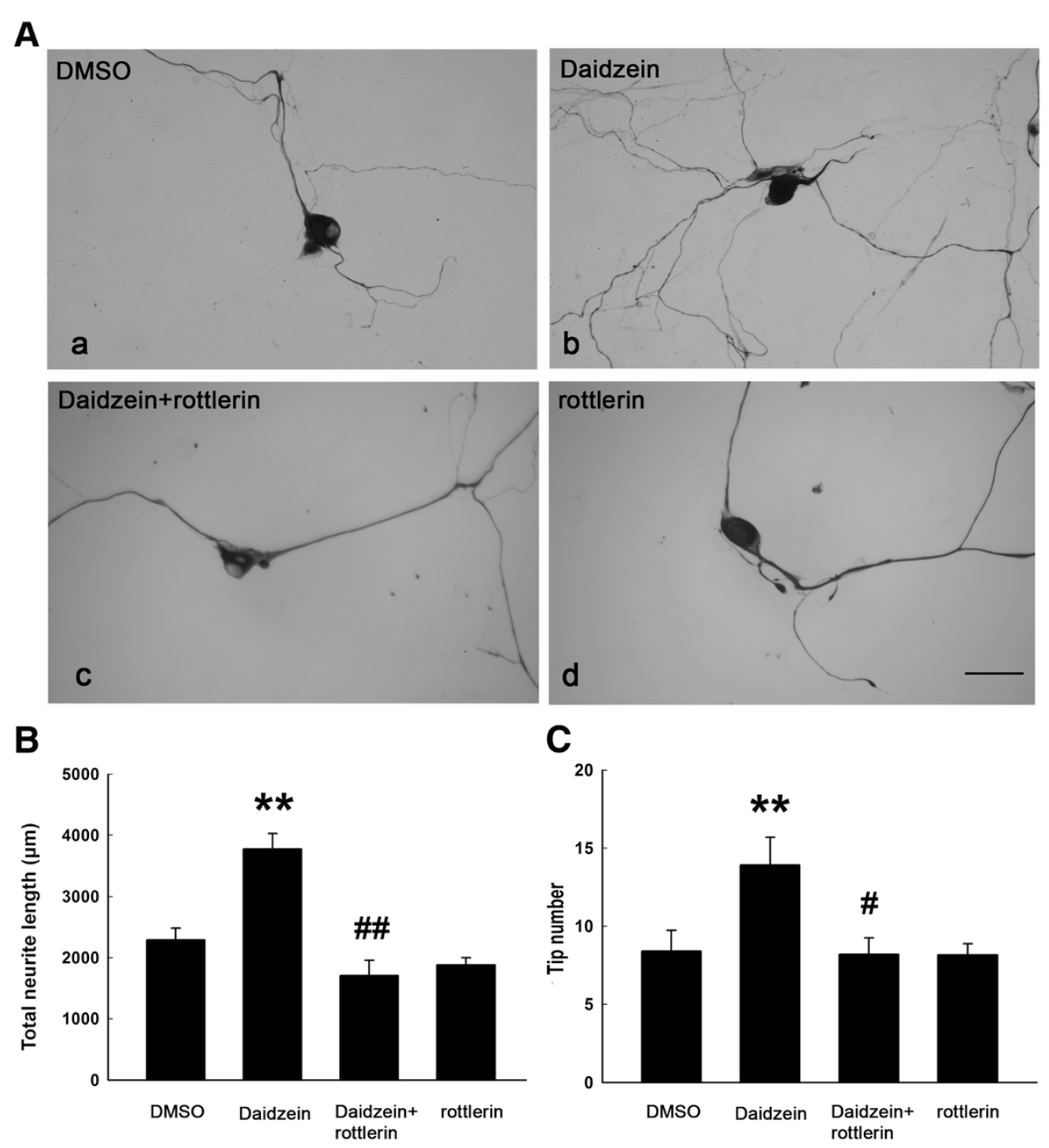

Figure 5 Blockage of daidzein-induced neuritogenesis by kinase inhibitors of PKC $\delta$. (A) DRG neuronal cultures were treated for $24 \mathrm{~h}$ with (a) DMSO, (b) $30 \mu \mathrm{M}$ daidzein or (d) $2 \mu \mathrm{M}$ PKC $\delta$ inhibitor rotterlin. Inhibitor assay was conducted by pretreatment of DRG neuronal cultures for 30 min with (c) $2 \mu \mathrm{M}$ rottlerin, followed by $30 \mu \mathrm{M}$ daidzein for $24 \mathrm{~h}$. The neurons were fixed and immunostained for NF-L. Scale Bar $=30 \mu \mathrm{m}$. Analysis of total neurite length $(\mathbf{B})$ and tip number $(\mathbf{C})$ revealed that rottlerin significantly blocked the neuritogenesis induced by daidzein. **, $p \leq 0.01$ vs DMSO; $\#, p \leq 0.05$ vs daidzein, \#\#, $p \leq 0.01$ vs daidzein. $N=10$.

the means of different groups, with p value of less than 0.05 considered significant.

\section{Results}

\section{Daidzein enhances neuritogenesis in cultured DRG neurons}

We first studied the effect of daidzein on neurite outgrowth in primary rat DRG neuronal cultures. DRG neurons were classified into large (diameter $\geq 40 \mu \mathrm{m}$ ) and small (diameter $\leq 40 \mu \mathrm{m}$ ) according to the criteria described by Gavazzi [33]. Based on cell diameter, smallsized unmyelinated neurons that are responsible for pain sensation, and large-sized myelinated that are for proprioception. DIV 3 neurons were incubated with different concentrations of daidzein, DMSO (negative control), or NGF (positive control) for $24 \mathrm{~h}$. Compared to DMSO-treated control cultures, daidzen treatment significantly enhanced neurite extension and branching of large DRG neurons (Figures 1, 2A-B). Quantitative analysis of total neurite length and tip numbers per neuron indicated that the minimal effective concentration of daidzein in promoting neurite outgrowth was $30 \mu \mathrm{M}$ (length, $4180 \pm 246 \mu \mathrm{m}$; tip number, $15.0 \pm 1.4$; DMSO, $2323 \pm 128 \mu \mathrm{m}$; tip number, $7.8 \pm 0.2 ; \mathrm{p} \leq 0.01, \mathrm{n}=10$ ), which had an effect similar to that of $100 \mathrm{ng} / \mathrm{ml}$ NGF (Figure 2) and was thus used for further study of the compound. The effect of daidzeininduced neuritogenesis was observed similarly in both small-sized and large-sized DRG neurons (Figures 1G-H, $2 \mathrm{C})$. Furthermore, to examine whether daidzen was toxic to DRG neurons, double staining of cells with DAPI and 


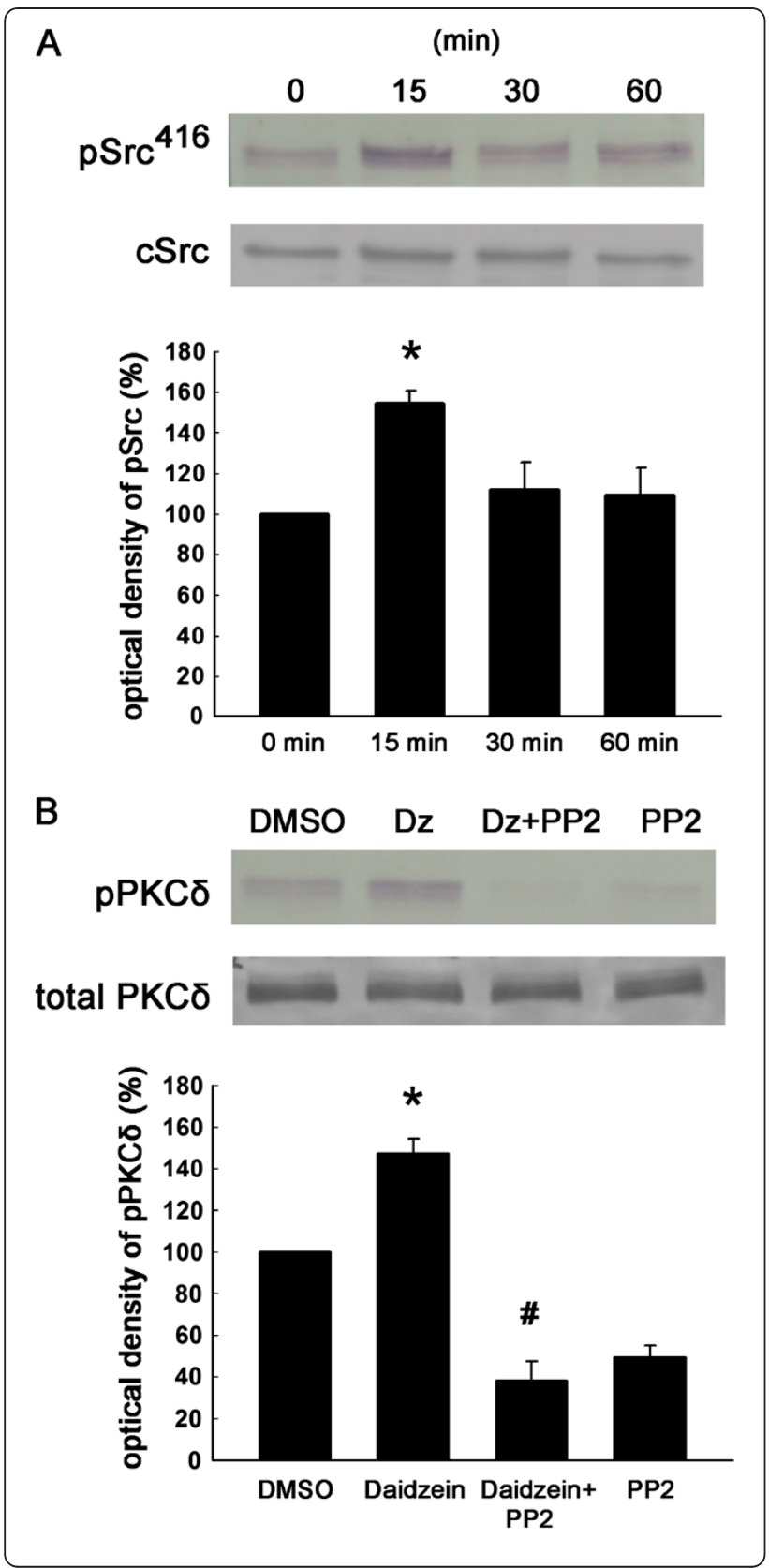

PI was performed to identify apoptotic and necrotic cells, respectively [34]. No apparent cell death was observed at $30 \mu \mathrm{M}$ by MTT assay (Figure 3A).

\section{Src and ERK inhibitors block neuritogenic effect of daidzein}

To investigate the signaling mechanism underlying the neuritogenic effect of daidzein, various inhibitors were applied to DRG neuronal cultures before and during daidzein treatment. Daidzein is structurally similar to estrogen and can activate ER in other cell culture systems [15,22]. Thus, we first examined this possibility. Treatment alone with
Figure 6 Activation of Src and PKC $\delta$ by daidzein treatment and suppression of the PKC $\delta$ activation by the specific Src inhibitor PP2. (A) Phosphorylation of Src following daidzein treatment was analyzed by Western blot analysis. DRG neuronal cultures were treated with $30 \mu \mathrm{M}$ daidzein for $0,15,30$, or $60 \mathrm{~min}$, then the cell homogenate was analyzed for phosphorylated Src (pSrc416) and total Src. Upper panel showed a representative blot from one experiment. Lower panel showed optical densities of the densitometric scans of the pSrc416 bands. Basal levels of phosphorylation in non-stimulated cells (DMSO) were taken as 100\% for each individual treatment. *, $p<0.05$ vs 0 min, $\mathrm{n}=4$. (B) Phosphorylation of PKC $\delta$ was analyzed by Western blot analysis. DRG neuronal cultures were given DMSO, $30 \mu \mathrm{M}$ daidzein (Dz) for $30 \mathrm{~min}, 10 \mu \mathrm{M}$ the Src inhibitor PP2 for $30 \mathrm{~min}$ followed by $30 \mu \mathrm{M}$ daidzein for $30 \mathrm{~min}$ (Dz+ PP2), or $10 \mu \mathrm{M}$ PP2 for $60 \mathrm{~min}$ (PP2). The cell homogenate was analyzed for phosphorylated and total PKC $\delta$. Upper panel showed a representative blot from one experiment. Lower panel showed optical densities of the densitometric scans of the PKC $\delta$ bands. PP2 treatment reduced both basal and. daidzein-induced PKC $\delta$ phosphorylation. *, $p<0.05$ vs DMSO; $\#, p<0.05$ vs daidzein. $n=4$.

inhibitors for ER- $\alpha / \beta$, GPR-30, Src, or MEK had no effect on total neurite length and tip numbers (Figure 3B, C). Neither the ER- $\alpha / \beta$ inhibitor ICI 182780 (length, $3778 \pm 101$ $\mu \mathrm{m}$, tip number, $10.9 \pm 0.9 \mu \mathrm{m}$; daidzein, length, $4145.8 \pm$ $255.5 \mu \mathrm{m}$, tip number, $12.9 \pm 0.8$; DMSO, length, $2363.2 \pm$ $128.5 \mu \mathrm{m}$, tip number, $9.3 \pm 0.9, \mathrm{n}=10$ ) nor the GPR-30 antagonist G15 (length, $3721 \pm 141 \mu \mathrm{m}$; tip number, 11.3 $\pm 0.9, \mathrm{n}=6$ ) blocked the daidzein-induced neurite lengthening or branching in our cultured DRG neurons (Figure 4). Another ER antagonist tamoxifen also did not inhibit daidzein-induced neuritogenesis (length, $2256.6 \pm$ $580 \mu \mathrm{m}, \mathrm{n}=10$; DMSO, $2629.4 \pm 436 \mu \mathrm{m}$; daidzein, 3632.7 $\pm 560 \mu \mathrm{m})$. On the other hand, both the Src inhibitor PP2 (length, $1971 \pm 101 \mu \mathrm{m}$, tip number, $6.7 \pm 0.4, \mathrm{n}=10$, $\mathrm{p} \leq 0.01$ daidzein, length $4145.8 \pm 255.5 \mu \mathrm{m}$, tip number $12.9 \pm 0.8$ control, length $2363.2 \pm 128.5 \mu \mathrm{m}$, tip number, $9.3 \pm 0.9$ ), and the MEK inhibitor U0126 (length, $2031 \pm$ 126 tip number, $10.0 \pm 0.7, \mathrm{n}=10, \mathrm{p} \leq 0.01$ ) significantly reduced daidzein-induced neuritogenesis (Figure 4). Treatment with PP2 or U0126 alone had no effect on cell survival, total neurite length, or tip numbers (Figure 3B, C).

\section{Blocking of the neuritogenic effect of daidzein by PKC $\delta$} inhibitor

To examine whether PKC involved in the daidzeininduced neuritogenesis, we treated DRG neurons with a pan-PKC activator PMA in the presence of the src kinase inhibitor PP2. The result showed that activation of PKC by PMA could reverse the PP2-induced decrease in total neurite length (PMA + PP2 + daidzein, length, $1999 \pm 85$ $\mu \mathrm{m}$; DMSO, $1768 \pm 77 \mu \mathrm{m}$; PP2 + daidzein, $1401 \pm 72 \mu \mathrm{m}$, $\mathrm{p} \leq 0.05, \mathrm{n}=5$ ).

To further investigate the signaling mechanism involved in the neuritogenic effect of daidzein, various PKC inhibitors were applied to DRG neuronal cultures. Neither 


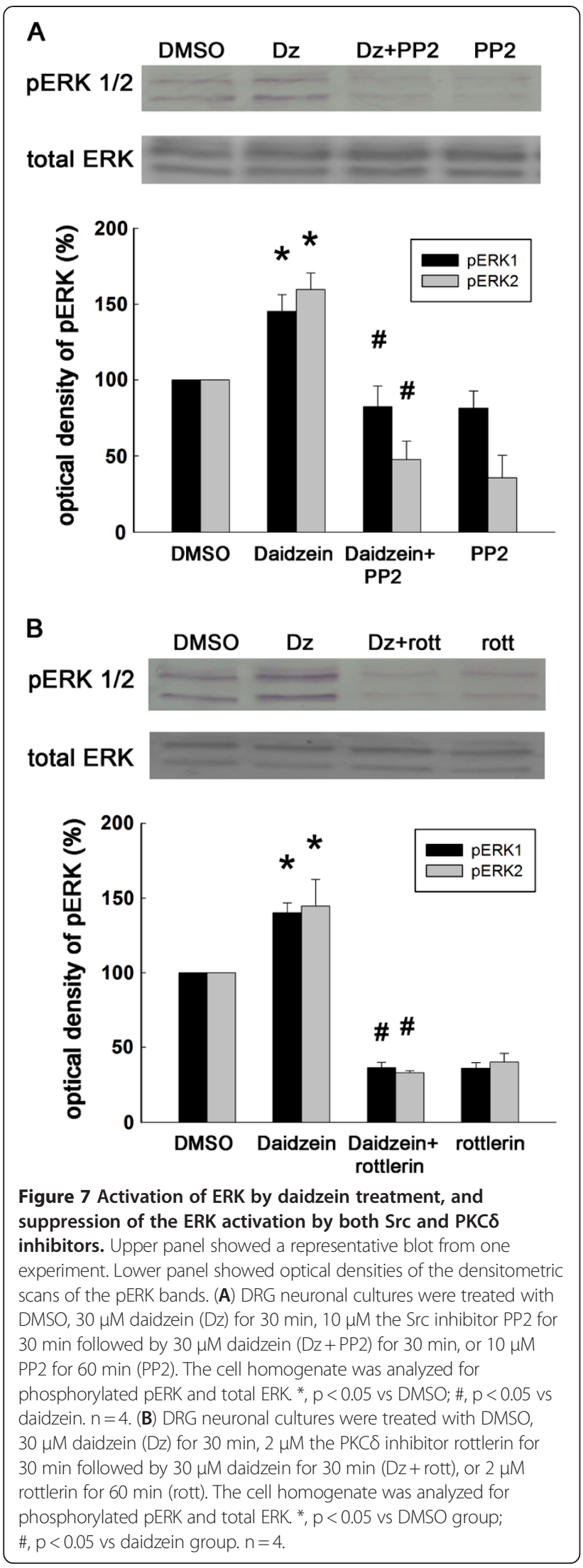

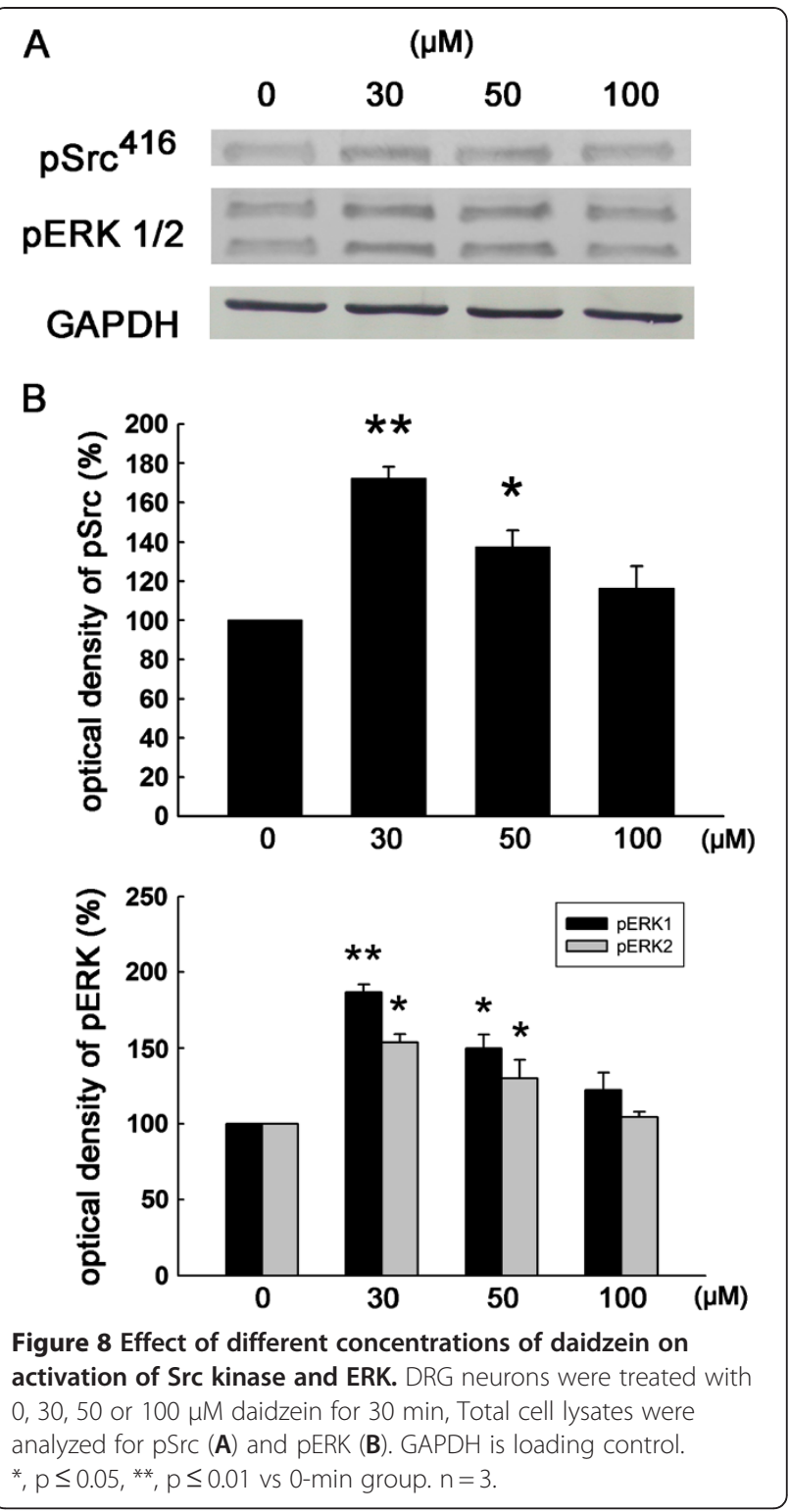

PKC $\alpha$ inhibitor Gö6976 (length and tip number, $3853 \pm$ $673 \mu \mathrm{m}$ and 17.4 \pm 0.6 ; daidzein, $3382 \pm 340 \mu \mathrm{m}$ and $18.0 \pm 1.0$, DMSO, $1982 \pm 512 \mu \mathrm{m}$ and $10.8 \pm 0.7, \mathrm{n}=10$ ) nor PKC€ inhibitor $€ \mathrm{~V} 1-2$ (length and tip number, $3424 \pm$ $482 \mu \mathrm{m}$ and $16.1 \pm 1.0, \mathrm{n}=10)$ had any effect on the daidzein-induced neuritogenesis. Only the PKC $\delta$ inhibitor rottlerin (length, $1705 \pm 247 \mu \mathrm{m}, \mathrm{n}=10, \mathrm{p} \leq 0.01$ ) significantly block daidzein's neuritogenic effect (length, daidzein $3770 \pm 252 \mu \mathrm{m}$; DMSO; $2291 \pm 193 \mu \mathrm{m}, \mathrm{n}=10$ ) (Figure 5). Treatment with Go66976, €V1-2 (data not shown) or rottlerin (Figure 5) did not affect total neurite length and tip numbers.

Daidzein treatment activates Src, PKC 8 , and ERK

We next examined whether daidzein could activate the Src, PKCS, or the ERK signaling pathway. By using Western 
blotting with antibodies directed against phosphotyrosine416 of active Src (pSrc416), we found that the pSrc416 level was significantly increased by daidzein treatment (Figure 6A). Interestingly, pPKC $\delta$ levels were also upregulated in the presence of daidzein treatment, and the Src kinase inhibitor PP2 significantly inhibited this activation of pPKC $\delta$ by daidzein (Figure 6B). Moreover, ERK1 and ERK2 were activated by daidzein, and this effect was suppressed by both the Src kinase inhibitor PP2 and the PKC $\delta$ inhibitor rottlerin (Figure 7). Interestingly, a dosedependent study of daidzein showed that a maximal activation of Src kinase and ERK was found at $30 \mu \mathrm{M}$ daidzein (Figure 8). This data correlates well with the previous observation that the optimal concentration of daidzein to achieve effective neurotigenic activity is $30 \mu \mathrm{M}$.

\section{Discussion}

Previously, in cultured osteoblastic cells, daidzein was shown to bind to cell membrane ER- $\beta$ to activate the phospholipase $\mathrm{C} \beta 2$ (PLC- $\beta 2$ )/PKC and PI3K/cSrc pathways, leading to the expression of several groups of genes for cell differentiation, proliferation, and migration [15]. Similarly, in macrophage, daidzein inhibited the activation of STAT-1 and NF-kB proteins, thereby decreased the expression of iNOS and the production of NO [35]. Moreover, in hippocampal neurons, daidzein was demonstrated to promote neurite outgrowth via $E R-\beta$, which in turn may increase the phosphorylation of $\mathrm{PKC} \alpha$ and growth associated protein 43 (GAP-43) [22]. In contrast to these ER-dependent signaling systems, here our results revealed that the neuritogenic effects of daidzein in DRG neurons did not mediate through ER $\alpha / \beta$ or GPR-30 (the third kind of ER receptor), as pretreatment of DRG neurons with specific estrogen receptor antagonists, ICI 182780, tamoxifen, or G-15, did not block the daidzeininduced neuritogenesis.

Most importantly, our studies showed that daidzein treatment increased the phosphorylation of Src kinase and ERK1/ERK2 in cultured DRG neurons. Src kinase, which is activated by various molecules like NGF, laminin, artemin, and anti-Thy-1 antibody, has been shown to be an important signaling pathway involved in the process of DRG neurite outgrowth [27,36,37]. Downstream signaling of Src includes MEK/ERK and PI3K/Akt pathways, which can be activated by NGF to induce neurite extension and branching of DRG neurons [38]. While inhibition of Src kinase by PP2 and suppression of ERK1/2 by U0126 abolished the neuritogenic effect of daidzein, inhibition of Akt by LY294002 had no effect (unpublished observation). Thus, the current study did not support the role of PI3K/Akt pathway in daidzeininduced neuritogenesis. The increased phosphorylation of ERK and daidzein-induced neuritogenesis was blocked by the Src kinase inhibitor PP2, indicating that promotion of neurite outgrowth by daidzein required Src kinase and ERK. As phosphorylated ERK could activate CREB, Cdk5, GAP-
43 and other neuritogenesis-related genes [39-41], it is possible that daidzein-induced neurite outgrowth is mediated by the Src-ERK pathway. Interestingly, PKC $\delta$ has been shown to be phosphorylated and activated by Src kinases in salivary and PC12 cells [42]. Consistent with this notion, we also found that daidzein increased the phosphorylation of PKC $\delta$, and that inhibition of PKC $\delta$ by a selective PKC $\delta$ inhibitor rottlerin resulted in the suppression of neurite outgrowth, suggesting that PKC $\delta$ may also play a role in the signaling cascade induced by daidzein. Different PKC isozymes, including PKC , have been found to be activated by neurotrophic agents. For examples, in PC12 cells the activation of ERK by neuritogenic agents, fibroblast growth factor (FGF) and NGF, was dependent on the activation of PKC [43]. In diabetic rats, over-expression of PKC could ameliorate the retarded neurite outgrowth of DRG neurons [44]. Additional studies are therefore required to elucidate the mechanistic link between daidzein-induced activation of the Src-PKC - -ERK pathway and the downstream signaling pathways that eventually lead to neuritogenesis.

As mentioned above, we have shown that daidzeininduced neuritogenesis in hippocampal and DRG neurons are mediated by ER-dependent [22] and ER-independent mechanisms, respectively. The precise reasons underlying this striking difference remain unclear. Intrinsic signaling pathways regulating neurite outgrowth could drastically vary among different types of neuronal cells [45,46]. For example, activation and inhibition of the small GTPase Rac1 promotes neurite outgrowths in hippocampal and DRG neurons, respectively $[47,48]$. Further experiments will be required to determine if the neuritogenic effect of daidzein is also differentially regulated in various regions of the nervous system.

In cultured rat hippocampal neurons, a low concentration of daidzein had neuroprotective action (at $3.9 \mu \mathrm{M}$ ), but it could not promote neuritogenesis or enhance neuronal survival [24]. Using relative affinity binding assay of cellular extracts, the affinity of daidzein for estrogen receptor was estimated to be several hundred times lower than estrogen [19]. Therefore, adequate amount of daidzein is required to achieve biological activities through the estrogen receptor pathways. Studies using daidzein at much higher concentrations (30 to $40 \mu \mathrm{M}$ ) in cultured hippocampal neurons indicate that daidzein can promote neurite extension and protect neurons from glutamate-induced cell death $[22,24]$. We demonstrated that daidzein at $30 \mu \mathrm{M}$ increased neurite lengthening and branching for DRG neurons, which was in accordance with the results of previously published reports. In addition, we found $30 \mu \mathrm{M}$ daidzein had a neuritogenic effect similar to that of NGF, indicating that daidzein had a robust neuritogenic property. Meanwhile, daidzein did not affect DRG neuronal survival at $30 \mu \mathrm{M}$. When daidzein was used at a concentration higher than $30 \mu \mathrm{M}$, the neuritogenesis was decreased. This finding is in agreement with the observed fact that both 
Src and ERK achieve the highest levels of phosphorylation at $30 \mu \mathrm{M}$ daidzein.

Our finding that daidzein facilitates neurite outgrowth of DRG and hippocampal neurons has important implications for the potential facilitation of neural regeneration $[49,50]$. Preliminary study using daidzein for the treatment of optic nerve injury in rats have shown promising results [23]. Neurite outgrowth is a fundamental step in the establishment of neural connections during development and following injury. It would be interesting to see if daidzein could improve sensory and cognitive function in various animal disease models, e.g. injuries of peripheral nerves, brachial plexus, and spinal cord, as well as Alzheimer's disease. On the other hands, the signaling mechanism of daidzein warrants further investigation. It has been shown that daidzein did not activate Src kinase via ERs, so other upstream regulators of Src could be the potential targets of daidzein. Many downstream effectors of ERK are associated with neurite outgrowth, and daidzein may preferentially activate some of those. Future research will be directed to tackle these questions.

\section{Conclusion}

Daidzein enhances neurite outgrowth of cultured rat DRG neurons which is mediated by cooperative action of $\mathrm{Src}$ kinase, PKC $\delta$, and MEK.

\section{Abbreviations \\ DIV: Day in vitro; DMSO: Dimethyl sulfoxide; DRG: Dorsal root ganglion; ER: Estrogen receptor; ERK: Extracellular signal-regulated kinase; GAP-43: Growth associated protein 43; GPR-30: G-protein coupled receptor 30; MEK: Mitogen-activated protein kinase/extracellular signal-regulated kinase kinase; MPP: 1-methyl-4-phenyl pyridium; MT: 3-[4, 5-dimethylthiazol- 2-yl]-2, 5-diphenyltetrazolium bromide; NF-L: Neurofilament light chain; NGF: Nerve growth factor; PBS: Phosphate buffered saline; PI3K: Phosphoinositide 3-kinase; PLC: Phospholipase C; PKC: Protein kinase C; PKCס: Protein kinase C subtype delta; TBS: Tris-buffered saline.}

\section{Competing interests}

The authors declare that they have no competing interests.

\section{Authors' contributions}

SHY: designed and carried out experiments, analyzed results and manuscript writing. CCL, JPS: performed DRG cultures, immunostaining. YC: western blotting analysis. CJJ: designed experiments, analyzed results and manuscript revision. SMW: designed experiments, analyzed results and manuscript revision. All authors read and approved the final manuscript.

\section{Acknowledgements}

This work was supported by a grant from the National Science Council, Republic of China (NSC 98-2314-B-002-044-MY3).

\section{Author details}

'Division of Neurosurgery, Department of Surgery, National Taiwan University Hospital, Taipei, Taiwan. ${ }^{2}$ Department of Anatomy and Cell Biology, College of Medicine, National Taiwan University, No. 1, Section 1, Jen-Ai Road, Taipei 10051, Taiwan. ${ }^{3}$ Department of Biology and Anatomy, National Defense Medical Center, Taipei, Taiwan. ${ }^{4}$ Institute of Anatomy and Cell Biology, School of Medicine, National Yang-Ming University, No. 155, Section 2, Li-Non Street, Taipei 12212, Taiwan.

Received: 22 March 2012 Accepted: 21 August 2012

Published: 29 August 2012

\section{References}

1. Franke AA, Custer LJ, Wang W, Shi CY: HPLC analysis of isoflavonoids and other phenolic agents from foods and from human fluids. Proc Soc Exp Biol Med 1998, 217:263-273.

2. Wang SW, Chen Y, Joseph T, Hu M: Variable isoflavone content of red clover products affects intestinal disposition of biochanin A, formononetin, genistein, and daidzein. J Altern Complement Med 2008, 14:287-297.

3. Ososki AL, Kennelly EJ: Phytoestrogens: a review of the present state of research. Phytother Res 2003, 17:845-869.

4. Cheskis BJ, Greger JG, Nagpal S, Freedman LP: Signaling by estrogens. J Cell Physiol 2007, 213:610-617.

5. Hwang CS, Kwak HS, Lim HJ, Lee SH, Kang YS, Choe TB, Hur HG, Han KO: Isoflavone metabolites and their in vitro dual functions: they can act as an estrogenic agonist or antagonist depending on the estrogen concentration. J Steroid Biochem Mol Biol 2006, 101:246-253.

6. Gikas PD, Mokbel K: Phytoestrogens and the risk of breast cancer: a review of the literature. Int J Fertil Womens Med 2005, 50:250-258.

7. Hedelin M, Lof M, Olsson M, Adlercreutz H, Sandin S, Weiderpass E: Dietary phytoestrogens are not associated with risk of overall breast cancer but diets rich in coumestrol are inversely associated with risk of estrogen receptor and progesterone receptor negative breast tumors in Swedish women. J Nutr 2008, 138:938-945.

8. Verheus M, van Gils CH, Keinan-Boker L, Grace PB, Bingham SA, Peeters PH: Plasma phytoestrogens and subsequent breast cancer risk. J Clin Oncol 2007, 25:648-655.

9. Marino M, Acconcia F, Ascenzi P: Estrogen receptor signalling: bases for drug actions. Curr Drug Targets Immune Endocr Metabol Disord 2005, 5: 305-314.

10. Segars $\mathrm{JH}$, Driggers PH: Estrogen action and cytoplasmic signaling cascades. Part I: membrane-associated signaling complexes. Trends Endocrinol Metab 2002, 13:349-354

11. Falkenstein E, Tillmann HC, Christ M, Feuring M, Wehling M: Multiple actions of steroid hormones-a focus on rapid, nongenomic effects. Pharmacol Rev 2000, 52:513-556.

12. Zhao C, Dahlman-Wright K, Gustafsson JA: Estrogen signaling via estrogen receptor beta\}. J Biol Chem 2010, 285:39575-39579.

13. Revankar CM, Cimino DF, Sklar LA, Arterburn JB, Prossnitz ER: A transmembrane intracellular estrogen receptor mediates rapid cell signaling. Science 2005, 307:1625-1630.

14. Chambliss KL, Wu Q, Oltmann S, Konaniah ES, Umetani M, Korach KS, Thomas GD, Mineo C, Yuhanna IS, Kim SH, Madak-Erdogan Z, Maggi A, Dineen SP, Roland CL, Hui DY, Brekken RA, Katzenellenbogen JA, Katzenellenbogen BS, Shaul PW: Non-nuclear estrogen receptor alpha signaling promotes cardiovascular protection but not uterine or breast cancer growth in mice. J Clin Invest 2010, 120:2319-2330.

15. de Wilde A, Heberden C, Chaumaz G, Bordat C, Lieberherr M: Signaling networks from Gbeta1 subunit to transcription factors and actin remodeling via a membrane-located ERbeta-related protein in the rapid action of daidzein in osteoblasts. J Cell Physiol 2006, 209:786-801.

16. Constantinou Al, Krygier AE, Mehta RR: Genistein induces maturation of cultured human breast cancer cells and prevents tumor growth in nude mice. Am J Clin Nutr 1998, 68:1426S-1430S.

17. Shao ZM, Wu J, Shen ZZ, Barsky SH: Genistein exerts multiple suppressive effects on human breast carcinoma cells. Cancer Res 1998, 58:4851-4857.

18. Vantyghem SA, Wilson SM, Postenka CO, Al-Katib W, Tuck AB, Chambers AF: Dietary genistein reduces metastasis in a postsurgical orthotopic breast cancer model. Cancer Res 2005, 65:3396-3403.

19. Kuiper GG, Lemmen JG, Carlsson B, Corton JC, Safe SH, van der Saag PT, van der Burg B, Gustafsson JA: Interaction of estrogenic chemicals and phytoestrogens with estrogen receptor beta. Endocrinology 1998, 139:4252-4263.

20. Guo JM, Xiao BX, Dai DJ, Liu Q, Ma HH: Effects of daidzein on estrogenreceptor-positive and negative pancreatic cancer cells in vitro. World J Gastroenterol 2004, 10:860-863.

21. Miller DR, Lee GM, Maness PF: Increased neurite outgrowth induced by inhibition of protein tyrosine kinase activity in PC12 pheochromocytoma cells. J Neurochem 1993, 60:2134-2144.

22. Wang $P$, Jeng $C J$, Chien $C L$, Wang SM: Signaling mechanisms of daidzeininduced axonal outgrowth in hippocampal neurons. Biochem Biophys Res Commun 2008, 366:393-400. 
23. Ma TC, Campana A, Lange PS, Lee HH, Banerjee K, Bryson JB, Mahishi L, Alam S, Giger RJ, Barnes S, Morris SM Jr, Willis DE, Twiss JL, Filbin MT, Ratan RR: A large-scale chemical screen for regulators of the arginase 1 promoter identifies the soy isoflavone daidzeinas a clinically approved small molecule that can promote neuronal protection or regeneration via a cAMP-independent pathway. J Neurosci 2010, 30:739-748.

24. Zhao L, Chen Q, Diaz Brinton R: Neuroprotective and neurotrophic efficacy of phytoestrogens in cultured hippocampal neurons. Exp Biol Med (Maywood) 2002, 227:509-519.

25. Chen $\mathrm{CH}$, Chen YJ, Jeng CJ, Yang SH, Tung PY, Wang SM: Role of PKA in the anti-Thy-1 antibody-induced neurite outgrowth of dorsal root ganglionic neurons. J Cell Biochem 2007, 101:566-575.

26. Desbarats J, Birge RB, Mimouni-Rongy M, Weinstein DE, Palerme JS, Newell MK: Fas engagement induces neurite growth through ERK activation and p35 upregulation. Nat Cell Biol 2003, 5:118-125.

27. Yang SH, Chen YJ, Tung PY, Lai WL, Chen Y, Jeng CJ, Wang SM: Anti-Thy-1 antibody-induced neurite outgrowth in cultured dorsal root ganglionic neurons is mediated by the c-Src-MEK signaling pathway. J Cell Biochem 2008, 103:67-77.

28. Keswani SC, Rosenberg B, Hoke A: The use of GAP-43 mRNA quantification in high throughput screening of putative neuroprotective agents in dorsal root ganglion cultures. J Neurosci Methods 2004, 136:193-195.

29. Neumann S, Woolf CJ: Regeneration of dorsal column fibers into and beyond the lesion site following adult spinal cord injury. Neuron 1999, 23:83-91.

30. Leclere PG, Norman E, Groutsi F, Coffin R, Mayer U, Pizzey J, Tonge D: Impaired axonal regeneration by isolectin B4-binding dorsal root ganglion neurons in vitro. J Neurosci 2007, 27:1190-1199.

31. Di Giovanni S, De Biase A, Yakovlev A, Finn T, Beers J, Hoffman EP, Faden Al: In vivo and in vitro characterization of novel neuronal plasticity factors identified following spinal cord injury. J Biol Chem 2005, 280:2084-2091.

32. Twentyman PR, Luscombe M: A study of some variables in a tetrazolium dye (MTT) based assay for cell growth and chemosensitivity. $\mathrm{Br} J$ Cancer 1987, 56:279-285.

33. Gavazzi I, Stonehouse J, Sandvig A, Reza JN, Appiah-Kubi LS, Keynes R, Cohen J: Peripheral, but not central, axotomy induces neuropilin-1 mRNA expression in adult large diameter primary sensory neurons. J Comp Neurol 2000, 423:492-499.

34. Willingham MC: Cytochemical methods for the detection of apoptosis. J Histochem Cytochem 1999, 47:1101-1110.

35. Hamalainen M, Nieminen R, Vuorela P, Heinonen M, Moilanen E: Antiinflammatory effects of flavonoids: genistein, kaempferol, quercetin, and daidzein inhibit STAT-1 and NF-kappaB activations, whereas flavone, isorhamnetin, naringenin, and pelargonidin inhibit only NF-kappaB activation along with their inhibitory effect on iNOS expression and NO production in activated macrophages. Mediators Inflamm 2007, 2007:45673.

36. Jeong DG, Park WK, Park S: Artemin activates axonal growth via SFK and ERK-dependent signalling pathways in mature dorsal root ganglia neurons. Cell Biochem Funct 2008, 26:210-220.

37. Tucker BA, Rahimtula M, Mearow KM: Src and FAK are key early signalling intermediates required for neurite growth in NGF-responsive adult DRG neurons. Cell Signal 2008, 20:241-257.

38. Markus A, Zhong J, Snider WD: Raf and akt mediate distinct aspects of sensory axon growth. Neuron 2002, 35:65-76.

39. Minano A, Xifro X, Perez V, Barneda-Zahonero B, Saura CA, RodriguezAlvarez J: Estradiol facilitates neurite maintenance by a Src/Ras/ERK signalling pathway. Mol Cell Neurosci 2008, 39:143-151.

40. Harada T, Morooka T, Ogawa S, Nishida E: ERK induces p35, a neuronspecific activator of Cdk5, through induction of Egr1. Nat Cell Biol 2001, 3:453-459.

41. Gundimeda U, McNeill TH, Schiffman JE, Hinton DR, Gopalakrishna R: Green tea polyphenols potentiate the action of nerve growth factor to induce neuritogenesis: possible role of reactive oxygen species. J Neurosci Res 2010, 88:3644-3655.

42. Benes C, Soltoff SP: Modulation of PKCdelta tyrosine phosphorylation and activity in salivary and PC-12 cells by Src kinases. Am J Physiol Cell Physiol 2001, 280:C1498-C1510.

43. Corbit KC, Foster DA, Rosner MR: Protein kinase Cdelta mediates neurogenic but not mitogenic activation of mitogen-activated protein kinase in neuronal cells. Mol Cell Biol 1999, 19:4209-4218.
44. Sakaue Y, Sanada M, Sasaki T, Kashiwagi A, Yasuda H: Amelioration of retarded neurite outgrowth of dorsal root ganglion neurons by overexpression of PKCdelta in diabetic rats. Neuroreport 2003, 14:431-436.

45. Gil OD, Zanazzi G, Struyk AF, Salzer JL: Neurotrimin mediates bifunctional effects on neurite outgrowth via homophilic and heterophilic interactions. J Neurosci 1998, 18:9312-9325.

46. Ko M, Zou K, Minagawa H, Yu W, Gong JS, Yanagisawa K, Michikawa M: Cholesterol-mediated neurite outgrowth is differently regulated between cortical and hippocampal neurons. J Biol Chem 2005, 280:42759-42765.

47. Fournier AE, Takizawa BT, Strittmatter SM: Rho kinase inhibition enhances axonal regeneration in the injured CNS. J Neurosci 2003, 23:1416-1423.

48. Schwamborn JC, Puschel AW: The sequential activity of the GTPases Rap1B and Cdc42 determines neuronal polarity. Nat Neurosci 2004, 7: 923-929.

49. Davies AM: Neurotrophins: neurotrophic modulation of neurite growth. Curr Biol 2000, 10:R198-R200

50. Yiu G, He Z: Glial inhibition of CNS axon regeneration. Nat Rev NeurosCi 2006, 7:617-627.

doi:10.1186/1423-0127-19-80

Cite this article as: Yang et al:: Daidzein induces neuritogenesis in DRG neuronal cultures. Journal of Biomedical Science 2012 19:80.

\section{Submit your next manuscript to BioMed Central and take full advantage of:}

- Convenient online submission

- Thorough peer review

- No space constraints or color figure charges

- Immediate publication on acceptance

- Inclusion in PubMed, CAS, Scopus and Google Scholar

- Research which is freely available for redistribution

Submit your manuscript at www.biomedcentral.com/submit
C Biomed Central 